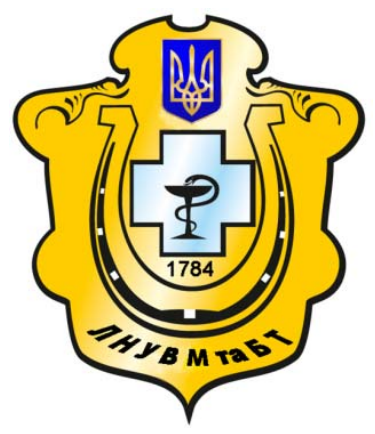

Науковий вісник Львівського національного університету ветеринарної медицини та біотехнологій імені С.З. Гжицького

Scientific Messenger of Lviv National University of Veterinary Medicine and Biotechnologies named after S.Z. Gzhytskyj

doi:10.15421/nvlvet7150

ISSN 2413-5550 print

ISSN 2518-1327 online

http://nvlvet.com.ua/

\title{
Frequency of dea 1.1 antigen in german shepherds
}

\author{
A. Milczak, Beata Abramowicz, Jacek Madany, Dagmara Winiarczyk, Karolina Wrześniewska, \\ Diana Bochyńska, Sima Sahinduran* \\ beata.abramowicz13@gmail.com
}

University of Life Sciences in Lublin, Veterinary Medicine Faculty, Department of Internal Diseases, Lublin, Poland
${ }^{*}$ Mehmet Akif Ersoy University, Department of Internal Medicine, Burdur, Turkey

Objectives: A correlation between blood type and the incidence of certain diseases in humans was established many years ago. It may be assumed that similar correlations could occur in dogs. Therefore, establishing the geographical and breed distribution of erythrocyte surface antigens in dogs may be of academic interest and useful in practice too. The aim of the study was the assessment of DEA 1.1 frequency among German Shepherds in the Lublin region of Poland.

Material and methods: Our study involved 20 German Shepherds from Eastern Poland. The presence of blood antigen was detected using a quick immunochromatographic test. In 9 cases a donor-recipient compatibility test was also performed.

Results: The antigen DEA 1.1 was detected in 15\% of dogs. A clear, macroscopically visible agglutination did not occur in any of the donor-recipient compatibility tests.

Conclusion: The breed studied may therefore be recognised as a suitable blood donor.

Key words: dogs, German Shepherds, blood, DEA 1.1 antigen, erythrocyte, quick immunochromatographic test, agglutination.

Citation:

Milczak, A., Beata Abramowicz, Jacek Madany, Dagmara Winiarczyk, Karolina Wrześniewska, Diana Bochyńska, Sima Sahinduran (2016). Frequency of dea 1.1 antigen in german shepherds. Scientific Messenger LNUVMBT named after S.Z. Gzhytskyj, 18, 3(71), 221-224.

\section{Introduction}

The correlation between blood type and the incidence of certain diseases in humans has been well-known for a significant period of time. For instance, individuals with blood type B are more susceptible to St. pneumoniae and $E$. coli infections. Also, during smallpox epidemics in the past the incidence of this disease was higher in people with blood type A (Korsak and Łętowska, 2009). It may be assumed that similar correlations occur in animals, including dogs. Unfortunately, as far as dogs are concerned we do not have any data to confirm this thesis. The current level of knowledge about the geographical distribution of erythrocyte surface antigens in dogs is still incomplete (Gračner et al., 2007; Arikan et al., 2009; Ognean et al., 2009; Kessler et al., 2010). Collecting data related to this problem would be a good starting point for further research. This could be accomplished by individual researchers sharing their data. Thus, cooperation between scientific centres is essential.

As well as producing scientifically significant results immunohaematological tests could also have practical applications. Due to the widespread use of blood transfusion therapy in veterinary medicine, establishing the blood types of the donor and the recipient is of fundamental importance for the assessment of transfusion safety. As far as dogs are concerned, the best-characterised incompatibility between the donor and the recipient in the blood group system DEA 1 may cause early transfusionassociated haemolytic reactions in this species (Corato et al., 1997; Hohenhaus, 2004; Ognean et al., 2009). A more complete set of data regarding the prevalence of the DEA 1.1 antigen in various breeds of dog would facilitate the search for blood group compatible donors.

The aim of our study was to assess the frequency of DEA 1.1 among German Shepherds in eastern Poland. This breed was chosen due to the fact that it is widely distributed all over the world. The results may serve as a starting point for mapping the global distribution of blood group antigens in the dog population. The general serological and antigenic characteristics of the blood of these dogs were also evaluated.

\section{Material and methods}

Blood samples were taken from 20 German shepherds for the purposes of this study. The group consisted of 12 
males $(60 \%)$ and 8 females $(40 \%)$. The ages ranged from 6 months to 11 years, with a mean of 5.5 years.

The dogs were under the supervision of the Department of Internal Diseases of Animals, University of Life Sciences in Lublin. Their owners brought them to the department for prophylactic examinations. The dogs were clinically healthy. Their medical history did not reveal any whole blood or blood component transfusions.

$5 \mathrm{ml}$ of blood from the cranial vena cava of the forelimb was collected for immunohaematological tests. $3 \mathrm{ml}$ of the blood was aspirated into a syringe tube with a coagulation activator, and $2 \mathrm{ml}$ was aspirated into a syringe from which $200 \mu \mathrm{l}$ of blood was taken to a tube containing K2 EDTA, while the remaining volume was diluted with sterile ACD solution at a 8:1 ratio and stored in a tube at $+4^{\circ} \mathrm{C}$. The presence of DEA 1.1 in EDTA whole blood was detected with the use of a quick immunochromatographic test (a quick immunochromatographic test Alvedia Canine Quick Test DEA 1.1) following the procedure recommended by the manufacturer. The results were described as follows: DEA $1.1(+)$ indicated the presence of the antigen, and DEA $1.1(-)$ indicated the absence of the antigen. The donor-recipient compatibility test was performed in 9 cases using a test tube method, which was a modification of the procedure proposed by the AVHTM

\section{Results}

In all cases the tests produced unambiguous results. No unexpected reactions were observed. The presence of DEA 1.1 was demonstrated in 3 males $(15 \%$ of the test group). In the remaining 17 animals (85\%), DEA 1.1 was not found.

A clear, macroscopically visible agglutination did not occur in any of the tests, haemolysis was not observed either. Weak agglutination reactions, confirmed by a microscopic examination (400 x magnification), were found in 6 dogs (Table 1). Blood cells in 2 DEA $1.1(+)$ dogs agglutinated in the presence of the serum of one DEA $1.1(+)$ animal and three DEA $1.1(-)$ animals. Blood cells in two DEA $1.1(-)$ dogs agglutinated in the presence of the serum of two other DEA $1.1(-)$ animals.

\section{Discussion}

Recently many test kits for the determination of canine red blood cell surface antigens have appeared on the market. The kits facilitate and accelerate testing, as well as eliminating the impact of inter-analyst variability of the results (Giger et al., 2003; Ognean et al., 2009; Kessler et al., 2010; Kohn et al., 2012). They have certainly contributed to the increasing interest in blood typing in veterinary practice.

In the last decade, numerous papers on the distribution of erythrocyte antigens in dogs have been published. The studies usually involve mongrels, less often, pure breeds of dogs. This is understandable due to the predominance of mongrels in the canine population of most countries. The frequency of DEA 1.1 in this group of dogs is estimated to be approximately $50 \%$ on average (Acierno et al., 2014). Data from various countries differ only slight- ly. In the USA, the percentage of DEA $1.1(+)$ dogs varies between $42 \%$ (Hohenhaus, 2004) and approximately $60 \%$ (Žubčić et al., 2008; Kessler et al., 2010) depending on the author of the study. In Argentina and Brazil, the antigen is found in $43 \%$ and $46 \%$ of dogs, respectively (Novais et al., 1999; Montoro et al., 2000). In Romania, the proportion is approximately $47 \%$, and in Switzerland $49 \%(20,23)$. A high percentage of DEA $1.1(+)$ mongrels $(82 \%)$ was only observed in Japan (Arikan et al., 2009).

The situation is different in the case of pure breed dogs. This group, considered as a whole, produces results similar to the mean value for mongrels (Montoro et al., 2000), but the differences become more significant when individual breeds are analysed (Riond et al., 2011). The breeds in which all animals are DEA $1.1(+)$ include St. Bernard Dogs (Ferreira et al., 2011) and Bernese Mountain Dogs (1). Over 90\%, of Rottweilers (Ferreira et al., 2011; Riond et al., 2011), Croatian Sheepdogs (Žubčić et al., 2008; Arikan et al., 2009) and Dalmatians in Croatia (Arikan et al., 2009) are DEA $1.1(+)$ animals. In the USA, $24 \%$ of the Dalmatians studied were DEA $1.1(-)$ (Blais et al., 2007). The breeds in which DEA 1.1 occurs with a frequency close to the average for the whole population include the Istrian Hound, Kangal Dog and the Spanish Greyhound (Arikan et al., 2009), whereas among breeds such as the Boxer (Riond et al., 2011), Greyhound (Arslan et al., 2007), Doberman (Ferreira et al., 2011) or Thai Ridgeback (Suwanna et al., 2008), virtually no animals with DEA 1.1 were found.

Ferreira (Ferreira et al., 2011) also considered the German Shepherd to be one of those breeds. In his study on a group of German Shepherds in Portugal he did not find any DEA $1.1(+)$ dogs. However, entirely different results were obtained by Hale in the USA in 1996 and Novais in Brazil in 1999 (Novais et al., 1999). They found that the proportion of DEA $1.1(+)$ in German Shepherds was $43.5 \%$ and $36.8 \%$, respectively. The study conducted by Novais in 2003 (Novais, 2003), revealed an even higher percentage of DEA $1.1(+)$ in German Shepherds (64\%). One of the studies conducted in Australia demonstrated that approximately $30 \%$ of local German Shepherds were DEA $1.1(+)$ (Merwe et al., 2002). Esteves (Esteves et al., 2011) in Porto Alegre obtained different data. Only $10 \%$ of the dogs he studied were DEA 1.1 (+). Van der Merwe (Merwe et al., 2002) from the Republic of South Africa estimated that the percentage of DEA $1.1(+)$ German Shepherds is $16 \%$. The results of the studies conducted in our clinic are similar to those presented by the last two authors in geographically distant regions $(16,19)$. As can be seen from the above review, different groups of German Shepherds are characterised by different frequencies of DEA 1.1. The differences can be explained by the small sizes of the test groups. The number of dogs studied by Fereira (Ferreira et al., 2011), Novais (Novais et al., 1999), Esteves (Esteves et al., 2011) and van der Merwe (Merwe et al., 2002) was 10, 19, 20 and 55, respectively. Moreover, the impact of geographical factors on the distribution of red blood cell surface antigens should not be disregarded. The most typical example of such correlations is the absence of antigens $\mathrm{A}$ and $\mathrm{B}$ in the $\mathrm{ABO}$ blood group system in South American Indians, or the absence of antigen B in 
Aborigines (Korsak and Łętowska, 2009). This phenomenon is associated with the fact that these communities developed in isolation, and with their adaptation to specific epidemiological conditions. However, such a correlation should not be expected in German Shepherds. The breed is relatively new, it has been introduced to various environments, and, more importantly, it is subject to different breeding procedures, depending on the region. According to Esteves (Esteves et al., 2011), the significant differences between the proportion of DEA 1.1 ( + ) in dogs studied in Portugal and in Brazil can be explained by the different developments of breeding lines $(18,19)$. It seems that the most appropriate way to explain the impact of the environment on the erythrocyte antigen's structure in dogs is to examine primary breeds in their place of origin. This is why the studies conducted by Arikan (Arikan et al., 2009) or Ergul Ekiz (Ergul et al., 2011) on the traditional Turkish dog breeds: Kangal, Akbash, Catalburun and Kars are of academic interest. The size of the study groups was relatively large, and the proportion of DEA $1.1(+)$ dogs in all four breeds was approximately $60 \%$. Precise characterisation of immunohaematological properties of pure breed dogs, in association with epidemiological data regarding their susceptibility to diseases, might help to explain the biological role of DEA in the future. In addition to this, German Shepherds may also be suitable for further investigation. A comparison of the prevalence and incidence of certain especially infectious diseases among dog groups with different distributions of
DEA 1.1 antigen may indicate the direction of future research.

The results of recipient - donor compatibility tests obtained in our studies confirm the widely acknowledged safety of blood transfusions for dogs. None of the tests revealed clearly visible agglutination; however, the percentage of weak reactions between the DEA $1.1(+)$ dogs and DEA 1.1 (-) animals was significant. Canine blood serum is not considered to contain natural isoagglutinins. In fact, this is not entirely true, as in $10-17 \%$ of DEA 1.1 (-) dogs the presence of naturally occurring anti-DEA 1.1 antibodies was detected. However, the titers of these isoagglutinins are very low; therefore, they are considered to have no clinical importance (Hohenhaus, 2004; Tiwari et al., 2009; Dallabona, 2013). Our study did not explain if the antibodies of the DEA 1 system were responsible for blood cell agglutination. This issue was beyond the scope of the study.

\section{Conclusion}

A small percentage of DEA $1.1(+)$ dogs $(15 \%)$ was found in the studied group of German Shepherds from the Lublin area. The studied breed may therefore be recognised as suitable blood donors. The occurrence of weak agglutination reactions in the compatibility tests justifies further studies regarding the complete characterisation of serological blood properties in the German Shepherd breed.

Table 1.

The results of recipient - donor compatibility tests between dogs № 2 to 10 . («S» - serum, «E» - RBC, «-» - no reaction, «+»- weak agglutination reactions, «NA»- not analysed)

\begin{tabular}{|c|c|c|c|c|c|c|c|c|c|}
\hline & 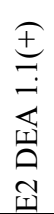 & 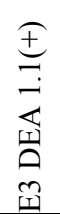 & 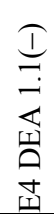 & 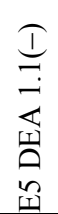 & 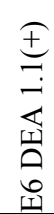 & 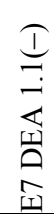 & 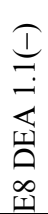 & 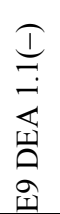 & 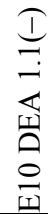 \\
\hline S2 DEA 1.1(+) & & - & - & - & - & - & - & + & - \\
\hline S3 DEA $1.1(+)$ & - & & - & - & - & - & - & NA & - \\
\hline S4 DEA $1.1(-)$ & - & - & . & + & - & - & - & - & - \\
\hline S5 DEA 1.1(-) & - & - & - & & - & - & - & - & - \\
\hline S6 DEA 1.1(+) & + & + & - & - & & - & - & + & + \\
\hline S7 DEA 1.1(-) & - & - & - & - & - & & - & + & - \\
\hline S8 DEA $1.1(-)$ & - & - & - & - & + & - & & NA & - \\
\hline S9 DEA 1.1(-) & + & + & - & - & + & - & - & & - \\
\hline S10 DEA 1.1(-) & + & + & - & - & - & - & - & - & \\
\hline
\end{tabular}

\section{References}

Acierno, M.M., Raj, K., Giger, U. (2014). DEA 1 Expression on Dog Erythrocytes Analyzed by Immunochromatographic and Flow Cytometric Techniques. J. Vet. Intern. Med. 29, 592-598.

Arikan, S., Guzel, Mamak, Ograk, Y.Z. (2009). Frequency of blood types DEA 1.1, 3, 4, 5, and 7 in Kangal dog. Revue Méd. Vét. 160, 180-183.

Arslan, M., İnal, G.N., Kayar, A. (2007). Blood Transfusion in Dogs. JIVS. 3, 11-24.
Blais, M-C., Berman, L., Oakley, D.A., Giger, U. (2007). Canine Dal Blood Type: A Red Cell Antigen Lacking in Some Dalmatians. J. Vet. Intern. Med. 21, 281-286.

Corato, A., Mazza, G., Hale, A.S., Barker, R.N., Day, M.J. (1997). Biochemical characterization of canine blood group antigens: immunoprecipitation of DEA 1.2, 4 and 7 and identification of a dog erythrocyte membrane antigen homologous to human Rhesus. Vet. Immunol. and Immunopathology. 59, 213-223.

Dallabona, D. (2013). Occurrence of Natural Antibodies Against Erythrocyte Antigens In Dogs From Sinop 
and Sorriso, MT, Brazil. Scientific Electronic Archives, edited by Federal University of Mato Grosso. 3, 33-37.

Ergul, E.E., Arslan, M., Ozcan, M., Gultekin, G.I., Gulay, O.Y., Kirmizibayrak, T., Giger, U. (2011). Frequency of dog erythrocyte antigen 1.1 in 4 breeds native to different areas in Turkey. Vet. Clin. Pathol. 40, 518523.

Esteves, V.S., Lacerda, L.A., Lasta, C.S., Pedralli, V., González, F.H.D. (2011). Frequencies of DEA blood types in a purebred canine blood donor population in Porto Alegre, RS, Brazil. Pesq. Agropec. Bras. 31, 178-181.

Ferreira, R.R.F., Gopegui, R.R., Matos, A.J.F. (2011). Frequency of dog erythrocyte antigen 1.1 expression in dogs from Portugal. Vet. Clin. Pathol. 40, 198-201.

Giger, U., Stieger, K., Airasmaa, H. (2003). Initial Comparison of Various Canine Blood Typing Methods. 21st Annual ACVIM Forum, Charlotte N.C., USA, 4-7 June, 383.

Gračner, D., Bedrica, L., Labura, Č., Matičić, D., Gregurić-Gračner, G., Samardžija, M. (2007). Blood groups and haematology in Istrian pointers. Vet. Arhiv. 77, 95-102.

Hohenhaus, A.E. (2004). Importance of Blood Groups and Blood Group Antibodies in Companion Animals. Transfus. Med. Rev. 18, 117-126.

Kessler, R.J., Reese, J., Chang, D., Seth, M., Hale, A.S., Giger, U. (2010). Dog erythrocyte antigens 1.1, 1.2, 3, 4,7 , and Dal blood typing and cross-matching by gel column technique. Vet. Clin. Pathol. 39, 306-316.

Kohn, B., Classe, G., Weingart, C. (2012). Clinical evaluation of the QuickVet $\AA /$ RapidVet $\AA$ canine $\operatorname{dog}$ erythrocyte antigen 1.1 blood-typing test. J. VET. Diagn. Incest. 24, 539-545.

Korsak, J., Łętowska, M. (2009). Immunohematologiczne podstawy współczesnej transfuzjologii. In: Transfuzjologia kliniczna. [Immunohematologic Principles of Contemporary Transfusiology. In: The Clinical Transfusiology]. 1st Ed, $\alpha$-medicapress, Bielsko-Biała, Poland, 34-45.

Merwe, L.L. van der, Jacobson, L.S., Pretorius, G.J. (2002). The breed prevalence of dog erythrocyte antigen 1.1 in the Onderstepoort area of South Africa and its significance in selection of canine blood donors. J. S. Afr. Vet. Assoc. 73, 53-56.

Montoro, A., Jacomet, L., Rivero, M.M., Giger, U. (2000). Frecuencia del grupo sanguíneo DEA 1.1 en caninos de Buenos Aires, Argentina. In Vet, 2(1), 5558.

Novais, A.A., Santana, A.E., Vicentin, L.A. (1999). Prevalence of DEA 1 canine blood group system in dogs (Canis familiaris, Linnaeus, 1758) reared in Brazil. Braz. J. Vet. Res. Anim. Sci. 36, 23-27.
Novais, A.A. (2003). Resultados. Tipagem Sangüínea dos Cães Domésticos (Canis familiaris). Cães da raça Pastor Alemão. In: Prevalencia dos antígenos eritrocitários caninos em caes domésticos (Canis familiaris) e investigaçao dos parâmetros hematológicos e da ocorrencia de antígenos eritrocitários em lobos-guará (Chrysocyon brachyurus) e cachorros-do-mato (Cerdocyon thos) criados no Brasil. [Results. Blood group typing in dogs (Canis familiaris), German Sheppard dogs. In: Prevalence of the erithrocyte antigens among dogs (Canis familiaris) and investigation of haemathological paramethers and occurance of the erythrocytes surface antigens in maned wolf (Chrysocyon brachyurus) and Crab-eating fox (Cerdocyon thos) in Brasil.] Doctoral thesis, Universidade Estadual Paulista «Júlio de Mesquita Filho» Faculty of the Agricultural and Veterinary Sciences, Jabotocabal, Brasil, 22-24.

Ognean, L., Masaji, W., Groza, I., Cernea, C., Muste, A., Muste, A., Pop, R., Mureşan, C. (2006). Încadarea şi tipizarea grupelor sanguine component ale unui nou system antigenetica la câine. [Specifying and typing blood group in dog using a new antigenic system.] Rev. Clujul. Med. Vet. 9, 18.

Ognean, L., Moldovan, M., Cernea, C., Cernea, M., Tripon, S. (2009). Blood Transfusion Compatibility Test In Dog And Other Pets. Annals of RSCB. 14, 118-122.

Perlado Chamizo M., Viñals Flórez L.M. (2010). Determinación del grupo sanguíneo Dog Erythrocyte Antigen (D.E.A 1.1) en Galgo Español para su uso como donante de sangre. [The Dog Erythrocyte Antigen (DEA 1.1) typing in blood of Spanish Greyhound in order to use them as a blood donor]. 45 SEVC conference, Barcelona, Spain, 30 september-3 October, 2010, Poster.

Riond, B., Schuler, E., Rogg, E., Hofmann-Lehmann, R., Lutz, H. (2011). Prevalence of dog erythrocyte antigen 1.1 in dogs in Switzerland evaluated with the gel column technique. Schweiz. Arch. Tierheilkd. 153, 369-374.

Suwanna, N., Noosud, J., Boonyaprakob, U., Choothesa, A., Sirinarumitr, T., Sirinarumitr, K. (2008). [Prevalence of DEA 1.1 Canine Blood Group System in Thai Ridge Back Dog.] Kasetsart. Veterinarians. $18,63-68$.

Tiwari, A.J., Balekar, N.S., Jain, D.K. (2009). Blood Group Systems and Blood Transfusion of Animals. Int. J. of Pharm. and Clin. Res. 1, 50-54.

Žubčić, D., Bedrica, L.J., Gračner, D., Harapin, I., Fury, M., Jeremić, J. (208). Blood groups, haematology and clinicochemical indicators in Croatian sheepdog. Vet. Arhiv. 78, 141-147.

Стаття надійшла до редакиії 5.10.2016 